\title{
KOLABORASI PERS, JURNALISTIK DAN WARTAWAN
}

Oleh

\section{M.YOSERIZAL SARAGIH}

\begin{abstract}
Abstraksi
Saat ini dunia jurnalistik tidak hanya milik wartawan professional saja tapi milik semua orang yang ingin berbagi informasi. Karena berbagai informasi yang dibutuhkan khalayak tidak selalu terpenuhi oleh media massa konvensional (umum). Adapun tulisan ini adalah ingin melihat lebih dalam bagaimana peran pers, jurnalistik dan wartawan juga bagaimana seharusnya menjadi seorang jurnalistik yang professional berdasarkan kode etik yang telah ada.
\end{abstract}

\section{Pendahuluan}

Orang sering menyamakan jurnalistik dan pers. Dan terkadang juga, lebih mudah untuk menyamakan jurnalistik sebagai surat kabar atau majalah. Hal ini disebabkan karena surat kabar merupakan media massa tertua dalam sejarah jurnalistik yang ditemukan manusia.

Istilah Pers berasal dari bahasa Belanda dan dalam bahasa lnggris berarti Press. Pers dalam arti luas adalah segala penerbitan bahkan termasuk media massa elektronik, Radio, dan televisi siaran, dan dalam arti sempit hanya terbatas pada dalam media massa cetak, surat kabar, majalah dan buletin kantor.

\section{Pengertian Pers}

Menurut Effendy pers adalah lembaga kemasyarakatan (Social Institution). ${ }^{1}$ Sebagai lembaga kemasyarakatan, pers merupakan sub sistem kemasyarakatan tempat ia berada bersama-sama dengan sub sistem lainnya. Dengan demikian pers tidak dapat hidup secara rnandiri, tetapi mempengaruhi dan dipengaruhi oleh lembaga-lembaga kemasyarakatan lainnya.

Selanjutnya dari sudut pandang oleh Nuruddin bahwa pers adalah, unsure pengolah data, peristiwa, idea tau gabungan ketiganya menjadi sebuah keluaran

\footnotetext{
${ }^{1}$ Effendy. Dalam Pikiran Rakyat, 1 September 1990.
} 
atau output kedalam system komunikasi. ${ }^{2}$ Artinya, berbagai informasi yang diolah lewat media menjadi hasil yang berguna bagi proses komunikasi. Pengertian lain mengenai pers dijelaskan oleh A. Hamzah dalam bukunya Pers Indonesia, bahwa pers adalah lembaga masyarakat dan alat perjuangan yang punya sebagai salah satu media komunikasi massa yang bersifat umum penerbitannya, dilengkapi dengan alat foto, klise, mesin dan alat-alat teknik lainnya. ${ }^{3}$

Dari ketiga defenisi diatas memberikan sebuah gambaran yang dapat dipahami, bahwa pers adalah sebuah lembaga social yang bergerak dalam bidang pemberitaan untuk dipublikasikan kepada khalayak baik itu secara harian mingguan atau priodik, terencana yang dapat dipertanggung jawabkan lembaga dan isi pemberitaannya.

\section{Fungsi Pers}

Menurut Assegaff fungsi utama dari pers adalah ${ }^{4}$ :

a. Memberikan informasi

b. Memberikan hiburan

c. Memberikan kontrol sosial

Sedangkan menurut Hoeta Soehoet, menjelaskan fungsi pers ada 6 yaitu $^{5}$ :

a. Melayani sistem politik dengan menyediakan informasi diskusi, dan perdebatan umum di masyarakat

b. Memberi penerangan kepada masyarakat sehingga masyarakat mampu mengatur diri sendiri.

c. Mengawal hak-hak asasi pribadi dengan mengabdi sebagai penjaga kewenangan pemerintah

d. Melayani sistem ekonomi dengan mempertemukan pembeli dan penjual barang atau jasa melalui iklan.

e. Menyajikan hiburan

${ }^{2}$ Nuruddin. Sistem Komunikasi Indonesia. Jakarta. Rajawali Pers, 2003.

${ }^{3}$ Hamzah, A. Delik-delik Pers di Indonesia, Jakarta. Media Sarana Press, 1987.

4 Assegaff, Dja'far H. Jurnalistik Masa Kini ( Pengantar Praktek Kewartawanan). Jakarta. Ghalia Indonesia, 1991.

${ }^{5}$ Hoeta Soehoet . Dasar - Dasar Jurnalistik. Jakarta. IISIP, 2003. 
f. Mengusahakan sendiri biaya finansial sehingga bebas dari tekanan-tekanan orang yang punya kepentingan. ${ }^{6}$

\section{Pengertian Jurnalistik}

Pada mulanya kegiatan jurnalistik ini hanya mengelola hal-hal yang sifatnya informatif saja. Ini terbukti pada Acta Diurna sebagai produk jurnalistik pertama pada zaman Romawi kuno ketika Julius Caesar berkuasa. Dalam perkembangannya, secara perlahan telah berubah fungsi dari yang hanya bersifat informatif menjadi sosial kontrol oleh kaum idealis. Bukan hanya menyebarkan informasi tetapi juga membujuk dan rnengajak khalayak untuk rnengambil suatu sikap tertentu agar berbuat sesuatu.

Jurnalistik berasal dari bahasa Belanda journalistick, jurnalistik ini merupakan terjemahan dari bahasa latin "diurna" yang berarti harian atau setiap harinya, yang terbit pada zaman Romawi ketika Julius Caesar berkuasa.

Jurnalisme tidak bermula dan tidak berakhir dengan cerita. Sikap ingin tahu adalah awal dan juga sekaligus dasar; seperti sebuah batu pertama yang berlanjut menjadi fondasi sebuah lorong. Setelah itu jurnalisme menempuhnya, dalam keadaan ruwet dan licin yang tidak saja membutuhkan keterampilan dan kecerdikan, tetapi juga kesediaan dan kemampuan untuk menjadi polisi lalu lintas, dan kemudian menjadi hakim dan jaksa untuk diri sendiri, yang awas terhadap pelanggaran.

Dalam abad modern sekarang ini, yang juga dengan kemajuan tekhnologi yang semakin canggih menyebabkan kehidupan masyarakat tidak dapat dilepaskan dari pers dan jurnalistik. Manusia sekarang ini tidak dapat hidup tanpa suguhan pers, karena mereka menganggap informasi sebagai suatu kebutuhan.

Menurut Effendy, Jurnalistik adalah suatu laporan harian yang menarik minat khalayak, mulai dari dari peliputan sampai pada penyebaran kepada masyarakat. ${ }^{7}$ Apa saja yang terjadi di dunia apakah peristiwa faktual (fact) atau pendapat seseorang (opinion) jika diperkirakan akan menarik perhatian khalayak,

\footnotetext{
6 Siebert, et al. Etika Pers Profesional Dengan Nurani. Bandung. Humaniora Utama Pers, 1986.

${ }^{7}$ Effendy. Dalam Pikiran Rakyat, 1 September 1990.
} 
akan merupakan bahan dasar jurnalistik, akan menjadi bahan berita untuk di sebarluaskan kepada masyarakat.

\section{Karakteristik dan Fungsi Jurnalistik}

Dalam Assegaff, menurut para ahli publisistik dan jurnalistik unsur-unsur berita antara lain adalah ${ }^{8}$ :

a. Termasa (terbaru)

Unsur baru merupakan yang terpenting bagi sebuah berita. Berita yang masih hangat akan menarik perhatian pembaca, dari pada berita yang sudah lama (basi).

b. Jarak (jauh atau dekat)

Jarak terjadinya suatu berita dengan tempat berita itu dipublisir mempunyai arti penting.

c. Keluarbiasaan

Sesuatu yang aneh, sesuatu yang luar biasa akan selalu menarik perhatian orang.

d. Akibat

Apabila berbicara mengenai berita yang menyangkut jarak, dekat atau jauh tempat kejadian dengan tempat publikasi berita, Carl Warren menyatakan yang paling penting menarik di dunia bagi manusia adalah sesuatu tentang dirinya sendiri.

Menurut Karl Batwizch mengemukakan lima syarat surat kabar adalah:

a. Publisitas

Surat kabar diterbitkan untuk publik, untuk masyarakat umum atau siapa saja. Siapapun boleh membeli dan membaca isinya bertujuan untuk diketahui masyarakat umum. Prioditas Surat kabar terbit pada waktu yang telah ditentukan sebelumnya. Priode terbit, jarak antara dua terbitan bersifat tetap dan teratur, misalnya, surat kabar harian sore terbit pada sore hari, kecuali hari libur.

b. Aktualitas

\footnotetext{
${ }^{8}$ Assegaff, Dja'far H. Jurnalistik Masa Kini ( Pengantar Praktek Kewartawanan). Jakarta. Ghalia Indonesia, 1991.
} 
Isinya aktual dan belum pernah dimuat sebelumnya, yaitu isi surat kabar yang menyangkut hal-hal yang hangat (baru atau aktual)

c. Universalitas

Isinya tidak rnengenai hanya satu persoalan saja, misalnya tidak hanya mengenai olah raga, isinya mengenai semua persoalan yang menjadi perhatian manusia seperti pendidikan, politik, sosial, budaya, hukum, ekonomi, kriminalitas dan lain sebagainya.

d. Kontiniutas

Isinya berkesinambungan, umpamanya surat kabar hari ini memuat berita pengadilan ketua DPR Akbar Tanjung, hendaknya pada terbit selanjutnya memuat pula berita persidangan sampai vonis hakim di jatuhkan.

Menurut Hoeta Soehoet, Ia mengatakan defenisi berita sebagai berikut ${ }^{9}$ :

a. Berita adalah keterangan mengenai peristiwa atau isi pernyataan manusia.

b. Berita bagi seseorang adalah keterangan mengenai peristiwa atau isi pernyataan manusia yang diperlukannya untuk mewujudkan filsafat hidupnya.

c. Berita bagi surat kabar adalah keterangan mengenai peristiwa atau isi pernyataan yang perlu bagi pembacanya untuk mewujudkan filsafat hidupnya.

Kembali, menurut Hoeta Soehoet ada empat faktor yang menentukan nilai berita bagi seseorang adalah:

a. Kegunaan berita

b. Aktualitas

c. Hubungan pembaca dengan peristiwa

d. KelengkaPan berita

Tujuan utama diantara semua tujuan jurnalistik adalah menyediakan informasi yang diperlukan agar orang bebas dan bisa mengatur diri sendiri. Dalam Kovach dan Rosentiel, ada sembilan unsur untuk memenuhi tugas utama jurnalistik adalah ${ }^{10}$ :

1. Kewajiban pertama adalah pada kebenaran

\footnotetext{
${ }^{9}$ Hoeta Soehoet . Dasar-Dasar Jurnalistik. Jakarta. IISIP, 2003.

${ }^{10}$ Rosentiel, Kovach, Bill. 2003, Sembilan Elemen Jurnalisme. Jakarta. Pantau, 2003
} 
Keinginan agar informasi adalah kebenaran elementer. Berita adalah materi yang digunakan untuk mempelajari dan berfikir tentang dunia di luar diri mereka maka kwalitas terpenting dari berita adalah bisa digunakan dan diandalkan.

2. Loyalitas pertama kepada warga

Kesetiaan pada warga adalah makna dari independensi, seperti ketidakterikatan, tidak berat sebelah, dan ketidak berpihakan terhadap informasi sehingga tidak menimbulkan kebingungan dan mencerminkan pemahaman orang menjadi kabur terhadap media.

3. Intisari iurnalisme adalah displin dalam verifikasi

Sikap ketidak berpihakan oleh wartawan, bukanlah prinsip dasar jurnalistik. Istilah netral ini, agaknya lebih sering digunakan oleh organisasi berita untuk mempromosikan diri bahwa mareka berupaya menghasilkan sesuatu yang diperoleh dengan metode obyektif.

4. Para praktisi harus menjaga independensi terhadap sumber berita

Dalam hal ini, lebih berakar dalanr pramatisme. Dimana seseorarng dapat membayangkan seorang wartawan dapat sekalipus menjadi peserta dalarn suatu peristiwa, tapi realitasnya mengaburkan semua tugas lain yang harus dilakukannya.

5. Jurnalisme harus berlaku sebagai pemantau kekuasaan Pers hadir untuk "menyusahkan orang senang dan menyenangkan orang susah”. Membuat makna anjing penjaga disalah pahami sehingga memberikan citra liberal (progresif), tujuan anjing penjaga juga berkembang ia tidak hanya menjadi manajemen dan pelaksana kekuasaan transparan semata. Tetapi juga menjadi akibat dari kekuasaan itu di ketahui dan dipahami oleh masyarakat (publik).

6. Jurnalisme harus menyediakan forum publik untuk kritik maupun dukungan warga, sehingga jurnalisme harus menyediakan sebuah forum untuk kritik dan kompromi publik.

7. Jumalisme harus berupaya membuat hal-hal yang penting Jurnalisme adalah mendorong dengan sebuah tujuan, menyediakan informasi yang dibutuhkan orang dalam memahami dunia. Tantangan pertama adalah 
informasi yang dibutuhkan orang untuk menjalani hidup mereka, yang kedua membuatnya bermakna, relevan dan enak disimak.

8. Jurnalisme harus menjaga agar berita komprehensif dan proporsional Mengupayakan jurnalisme sebagai pembuatan peta membantu kita melihat proporsi dan komprehensifitas adalah sebuah kunci dari akurasi.

9. Para praktisi harus dibolehkan rnengikuti hati nurani mereka pengertian hati nurani adalah sesuatu yang dipercayai dalam-dalam oleh sebagian besar wartawan. Dimana mereka merasakan jurnalisme adalah sebuah tindakan moral, dan tahu bahwa semua latar belakang dan menilai yang mereka miliki bias mengarahkan pada apa yang akan dikerjakan dan atau tidak dikerjakan dalam membuat berita.

\section{Idealisme Pers dan Jurnalistik}

\section{a. Idealisme sebagai ciri hakiki}

Idealisme merupakan ciri hakiki dari pers dan jurnalistik, sebab inilah yang menentukan tinggi rendahnya nilai pers. Tanpa idealisme pers hanyalah sekedar perusahaan biasa yang tidak ada bedanya dengan perusahaan lain seperti pabrik rokok.

Apabila kita berbicara mengenai pers maka, pers yang dibahas adalah pers yang bebas. Pers bebas ini mempunyai dua pengertian, yakni bebas dalam struktural dan bebas dalam ideal. Pers yang bebas struktural adalah pers yang tidak dimiliki oleh pemerintah, pers yang bebas ideal adalah pers yang bebas menyatakan pendapatnya.

Pers yang tidak bebas strukturalnya tidak perlu dipersoalkan mengenai kebebasan idealnya, karena sudah tentu akan membawakan suara pemerintah. Problematic pers struktural adalah pengendalian terhadap keseimbangan antara dimensi komersial dan dimensi ideal. Apabila pers, dimensi komersilnya lebih tinggi maka ia lidak layak disebut sebagai perusahaan pers.

\section{b. Fungsi mempengaruhi}

Ciri idealisme pers tampak dalam pelaksanaan fungsi pers, yaitu bukan hanya sekedar menyebarkan informasi (to inform), mendidik (to educate), dan 
menghibur (to entertain), melainkan juga melaksanakan fungsi mempengaruhi (to influence), dan melakukan pengawasan masyarakat (sosial kontrol). Kedua fungsi terakhir ini menyebabkan pers mendapat julukan "the fuorth estate" atau kekuasaan keempat.

Idealisme yang melekat pada pers tidak berarti selalu harus mengkritik pemerintah, apalagi mencari kesalahan-kesalahan pemerintah. Idealisme pada dasarnya harus mengandung keseimbangan antara menghargai dan mengkritik. Dimana bila pemerintah melakukan suatu kebaikan, patut dipuji walaupun itu memang kewajibannya, sebaliknya bila pemerintah berbuat salah patut dikritik, dan kritik ini bukan sekedar menunujukkan kesalahan tetapi juga rnemberikan jalan keluarnya disertai dengan arguman yang logis.

\section{Kewartawanan}

\section{Pengertian wartawan}

Jurnalistik dan pers tidak dapat dipisahkan dari wartawan. Sebab wartawan merupakan obyek yang menjadi pelaksana dari kegiatan jurnalistik. Pers menurut Undang-undang pokok pers No.40 tahun 1999 pasal I ayat (4), yaitu, wartawan adalah orang yang secara tcratur melaksanakan kegiatan jurnalistik. Dimana tugas tugas wartawan atau jurnalis adalah mengatur cara penyampaian isi pernyataan manusia dengan menggunakan media massa priodik seperti surat kabar majalah, tabloid, radio, televise, Film.

Rasa ingin tahu manusia terhadap segala peristiwa yang terjadi setiap waktu di seluruh alam semesta ini dan semua isi pernyataan sesama manusia dimana pun Ia tinggal dan apapun status sosialnya.Misalnya suka duka manusia baik teman, keluarga,maupun tentang manusia apakah ia tinggal di rimba raya Uganda ataupun di pencakar langit New York, mengenai peristiwa alam seperti gempa bumi, banjir dan lain sebagainya.

Untuk memperoleh informasi mengenai peristiwa dan isi pernyataan yang diperlukannya itu, manusia harus aktif mencari baik secara langsung maupun tidak langsung. Secara langsung dapat dilakukan dengan observasi (mengamati) keadaan, seperti cuaca, suhu udara dan lain sebagainya, secara tidak langsung dapat dilakukan dengan cara mengirim surat. 
Dari hal diatas, apabila setiap manusia mencari sendiri informasi (keterangan) mengenai semua peristiwa dan isu pernyataan yang diperlukan, tentu Ia tidak akan mempunyai waktu dan biaya yang cukup. Sebagian manusia memperhatikan hal ini untuk mengetahui informasi mengenai semua peristiwa dan isi pernyataan untuk memudahkan mewujudkan filsafat hidupnya.

Setelah menimbang fakta tersebut, manusia mengambil kesimpulan, bahwa ia akan membantu mencari dan mengumpulkan informasi itu. Kemudian diperbanyak dan akan dijual kepada siapa yang memerlukannya. Hal inilah yang menyebabkan lahirnya prof'esi wartawan dan muncullah surat kabar.

Menurut Widodo wartawan adalah Orang-orang yang pekerjaannya mencari berita dan kewartawanan adalah pekerjaann, kegiatan, usaha yang berhubungan dengan pengumpulan, penggolahan dan penyiaran dalam bentuk fakta, pendapat, ulasan, gambar-gambar dan sebagainya untuk perusahaan, radio, televisi, dan film. ${ }^{11}$

Menurut Simbolon, syarat untuk menjadi seorang wartawan adalah ketekunan, kegigihan dan vitalitas. ${ }^{12}$ Sedangkan vitalitas merupakan hal atau syarat utama seorang wartawan karena seorang wartawan harus dapat mengerjakan hal yang biasa dengan cara yang luar biasa.

\section{Wartawan sebagai Profesi}

Secara etimologis, istilah "profesi" bersumber dari bahasa Latin, frofessio yang secara harfiah berarti "sumpah keagamaan". Tetapi kini pengertian profesi, tidak hanya mengandung makna keagamaan, melainkan juga keilmuan. ${ }^{13}$ Profesi sebagai bidang pekerjaan yang dilandasi oleh pendidikan keahlian tertentu itu kita terima, pendidikan keahlian yang dimaksud setidaknya meliputi lima macam segi, ${ }^{14}$ yakni:

a. Penguasaan teori sistematis yang melandasi praktek profesi.

\footnotetext{
${ }^{11}$ Widodo. Tehnik Wartawan Menulis Berita di Surat Kabar dan Majalah. Surabaya. Indah, 1997.

12 Simbolon, Parakitri. Vademekum Wartawan. Jakarta. Gramedia, 1997.

13 Effendy. Dalam Pikiran Rakyat, 1 September 1990.

${ }^{14}$ Sudarminta. Methode Penelitian Komunikasi. Medan. USU Press, 1993.
} 
b. Pengusaan metode atau teknik intelektual yang merupakan semacam jembatan antara teori dan penerapannva dalam praktek.

c. Pemilikan kemampuan untuk menerapkan dalam praktek teknik intelaktual terssebut pada urusan Praktis.

d. Pemilikan kemampuan untuk menyelesaikan program latihan dan memperoleh ijazah, sertifikat atau tanda lulus untuknya.

e. Pemilikan pengalaman yang mencukupi di lapangan.

Wartawan sebagai suatu profesi, merupakan suatu pekerjaan yang menarik dan penuh tantangan. Menarik karena profesi kewartawanan sekarang ini berbeda dengan profesi kewartawanan sepuluh tahun yang lalu. Kemajuan ekonomi dan sistem pasar sekarang ini, telah mendorong kemajuan media massa, khususnya surat kabar dalann suatu dimensi baru.

Surat kabar telah berkembang menjadi sebuah industri besar, dengan kemajuan ini menyebabkan bahwa secara ekonomis penghasilan seorang wartawan jauh lebih baik tetapi hal ini juga mengakibatkan timbulnya jarak antara perusahaan dengan pekerja seperti yang diungkapkan oleh Chowdhuri “membesarnya perusahaan penerbitan, akan menciptakan kekuasaan yang besar pula pada pimpinan perusahaan (direksi), sehingga kekuasaan beralih dari tangan pimpinan redaksi ke pimpinan usaha penerbitan".

Dalam pengertian sempit, kewartawanan adalah kegiatan yang berhubungan dengan bentuk penulisan untuk media komunikasi massa (media of mass communication).

Dalam memenuhi naluri ingin tahu pcmbacanya redaksi atau wartawan mengumpulkan berita dari sumber berita, dan sumber berita ini dapat dibagi dua yaitu :

\section{a. Peristiwa}

Peristiwa yang dijadikan sumber berita disini, maksudnya adalah segala kegiatan yang dapat dijadikan sebagai sumber informasi dan informasi itu menyangkut orang banyak, seperti gempa banjir, tabrakan dan lain sebagainya.

b. Manusia

Biasanya manusia diartikan sebagai sumber berita, karena ia memberikan keterangan atau pendapat yang juga menyangkut kepentingan orang banyak, 
baik dari segi sosial, politik, budaya, pendidikan, agama, ekonomi dan sebagainya.

Dalam dunia kewartawanan, wartawan dapat dibedakan antata lain adalah:

a. Wartawan profesional

Wartawan yang menjadikan wartawan sebagai profesi.

b. Wartawan free lance

Wartawan yang tidak tergantung pada satu surat kabar saja. Dimana wartwan ini melakukan kegiatannya sebagai wartawan tetapi karyanya di kirimkan ke media lain, dengan kata lain ia tidak terikat pada satu media saja.

c. Koresponden

Istilah ini sering disebutkan pada wartawan yang berada daerah-daerah dan tidak berada dalam satu wilayah, kota dengan pusat penerbitan.

d. Wartawan kantor berita

Wartawan yang mencari berita untuk suatu kantor berita. Kemudian berita tersebut dijual atau disalurkan ke lembaga penerbitan yang mernbutuhkan.

\section{Wartawan Profesional}

Ciri-ciri dan persyaratan untuk menjadi wartawan profesional, Menurut B. Barber dalam The Profession mengemukakan empat kriteria untuk menjadi Profesional dalam suatu pekerjaan yakni:

1. Pengetahuan umum yang tinggi.

2. Lebih berorientasi pada kepentingan umum dibandingkan dengan kepentingan sendiri.

3. Ada pengawasan yang ketat atas prilaku pribadi melalui kode etik yang dihayati dalam proses sosialisasi pekerjaan serta melalui asosiasi-asosiasi suka rela yang diorganisasikan dan dijalankan oleh pekerja spesialis itu sendiri.

4. Sistem balas jasa (baik berupa uang dan kehormatan) yang merupakan lambang prestasi kerja sehingga menjadi tujuan, bukan alat untuk mencapai tujuan kepentingan pribadi. 
Menurut Winarto lima ciri untuk dapat menggolongkan sesuatu pekerjaan itu sebagai profesi ${ }^{15}$ :

1. Ada keahlian ( yang diperoleh dari pendidikan dan pengalaman).

2. Ada tanggung jawab terhadap kode etik profesi.

Kode etik Wartawan Indonesia bertujuan untuk menjamin tegaknya kebebasan pers serta terpenuhinya hak-hak masyarakat. Wartawan Indonesia menetapkan Kode Etik sebagai berikut:

a) Wartawan Indonesia menghormati hak masyarakat untuk memperoleh informasi yang benar.

b) Wartawan Indonesia menempuh cara-cara yang etis untuk rnemperoleh dan menyiarkan informasi serta memberikan identitas kepada sumber informasi.

c) Wartawan Indonesia menghormati asas praduga tak bersalah, tidak mencampurkan fakta dengan opini, berimbang dan selalu meneliti kebenaran informasi serta tidak melakukan plagiat.

d) Wartawan Indonesia tidak menyiarkan informasi yang bersifat dusta, fitnah, sadis, dan cabul, serta tidak menyebutkan korban kejahatan susila.

e) Wartawan Indonesia tidak menerima suap dan tidak menyalah gunakan profesi.

f) Wartawan Indonesia memiliki Hak Tolak, menghargai ketentuan embargo, informasi latar belakang, dan off the record sesuai kesepakatan.

g) Wartawan Indonesia segera mencabut dan meralat kekeliruan dalam pemberitaan serta melayani Hak Jawab.

3. Ada solidaritas profesi (menyadari bahwa apapun tindakannya berdampak pada citra profesi).

4. Ada panggilan dan keterikatan dengan pekerjaan itu dan mayoritas penghasilan berasal dari pekerjaan itu.

Menurut Terence J. Johnson dalam Profesi dan Kekuasaan mengemukakan enam kriteria untuk rnenjadi profesional dalam suatu pekerjaan yakni:

1. Keterampilan yang didasarkan pada pengetahuan teoritis

2. Penyediaan latihan dan pendidikan

3. Pengujian kemampuan anggota

\footnotetext{
${ }^{15}$ Winarto , Paulus. How To Handle The Journalist. Jakarta. Elex Media Komputindo, 2003.
} 


\section{Organisasi}

5. Kepatuhan kepada suatu aturan main profesional

6. jasa-pelayanan yang sifatnya altuistik

Berdasarkan uraian diatas, dapat disimpulkan bahwa profesi mengandung arti suatu pekerjaan dengan keahlian khusus yang menuntut adanya pengetahuan luas dan tanggung jawab, diabdikan untuk kepentingan orang banyak. Mempunyai organisasi atau asosiasi profesi dan mendapat pengakuan masyarakat serta mempunyai kode etik.

Istilah "profesionalisme" menunjukkan tahap-tahap dimana kemajuan pekerjaan (occupation progress) menjadikan adanya profesi. ${ }^{16}$

Profesi dipandang sebagai fenomena relatif, tidak mutlak. Suatu pekeriaan dapat dikatakan lebih profesional dari pada pekerjaan lainnya, karena memiliki unsur-unsur profesional yang lebih dari pekerjaan lainnya.

Profesionalisme adalah paham yang menilai tinggi keahlian professional khususnya, atau kemampuan kemampuan pribadi pada umumnya, sebagai alat utama untuk meraih keberhasilan.

Menurut Djisman Simanjuntak, profesionalisme bukan saja menyangkut tata nilai yang dianut orang perorang atau pun organisasi, melainkan juga mewujud dalam perilakunya.

Pada umumnya, ada lima hal yang menurut sosiolog tercakup profesionalisme, yang disarankan sebagai struktur sikap yang diperlukan bagi setiap jenis profesional.

a. Profesional menggunakan organisasi atau kelompok profesional sebagai kelompok referensi utama.

b. Profesional melayani masyarakat

c. Profesional memiliki kepedulian atau rasa terpanggil dalam bidangnya

d. Profesional memiliki rasa otonomi

e. Profesional mengatur diri sendiri (self regulation)

\footnotetext{
${ }^{16}$ Effendy. Dalam Pikiran Rakyat, 1 September 1990.
} 
Hal utama yang membedakan dari entrepreneurs adalah perbedaan nilai. Dimana para profesional tidak meletakkan imbalan sebagai tujuan utama, sungguh pun menganggapnya sebagai hal yang perlu.

Bagaimanapun juga wartawan merupakan sebuah profesi yang seharusnya disejajarkan dengan profesi lainnya, termasuk dengan para manajer. Memang, untuk menjadi seorang wartawan yang baik dan Profesional tidaklah mudah karena itu sebuah proses yang panjang dengan sikap tak putus asa untuk terus belajar dari pengalaman orang lain dan buku.

Wartawan yang baik mampu bekerja keras (work hard) dan bekerja cerdas (work smart), tetapi kritis tanpa merusak hubungan dengan sumber- sumber berita serta lihai sekaligus tulus mencari persahabatan, dan hanya jam terbang yang tinggi yang mampu dan dapat membentuk seseorang menjadi wartawan yang tangguh.

\section{Persepsi Korelasi Pers, Jurnalistik dan Wartawan}

Pengertian Persepsi

Persepsi sebagai salah satu fungsi jiwa yang pokok dapat diartikan gambaran ingatan dari pengamatan, dimana obyek telah diamati tidak lagi berada dalam ruang dan waktu pengamatan. Persepsi adalah inti dari komunikasi, sedangkan penafsiran (interpretasi) adalah inti persepsi yang identik dengan penyandian balik (decoding) dalam proses komunikasi.

La Boueuf mengatakan bahwa persepsi adalah pemahaman kita terhadap apa yang kita alami. Penafsiran kita terhadap apa yang kita lihat dan kita dengar, yang dipengaruhi oleh kombinasi antara pengalaman dan masa lalu, keadaan serta psikologi seseorang. ${ }^{17}$

Menurut Mc Mahon persepsi diartikan sebagai penginterpretasian rangsangan (input) dengan menggunakan alat penerima informasi (sensory Information) bahwa persepsi diartikan sebagai suatu proses dimana seseorang menerima, memilih dan menafsirkan. ${ }^{18}$

\footnotetext{
${ }^{17}$ La Boueuf. Methode Penelitian. Jakarta. Grasindo, 1992.

18 Isbandi. Dasar - Dasar Jurnalistik. Surabaya. Kartika, 1994.
} 
Untuk itu, setelah kita memahami apa itu persepsi maka kita dapat melihat bahwa pers adalah eksekusi konkrit dari unsure kerja jurnalistik yang objek pelakunya adalah wartawan. 


\section{Kesimpulan}

A. Bahwa pers adalah sebuah lembaga social yang bergerak dalam bidang pemberitaan untuk dipublikasikan kepada khalayak baik itu secara harian mingguan atau priodik, terencana yang dapat dipertanggung jawabkan lembaga dan isi pemberitaannya.

B. Fungsi utama dari pers adalah memberikan informasi, memberikan hiburan, memberikan kontrol social dan educasi.

C. Jurnalistik adalah suatu laporan harian yang menarik minat khalayak, mulai dari dari peliputan sampai pada penyebaran kepada masyarakat. Apa saja yang terjadi di dunia apakah peristiwa faktual (fact) atau pendapat seseorang (opinion) jika diperkirakan akan menarik perhatian khalayak, akan merupakan bahan dasar jurnalistik, akan menjadi bahan berita untuk di sebarluaskan kepada masyarakat.

D. wartawan adalah Orang-orang yang pekerjaannya mencari berita dan kewartawanan adalah pekerjaann, kegiatan, usaha yang berhubungan dengan pengumpulan, penggolahan dan penyiaran dalam bentuk fakta, pendapat, ulasan, gambar-gambar dan sebagainya untuk perusahaan, radio, televisi, dan film.

E. Pers adalah eksekusi konkrit dari unsure kerja jurnalistik yang objek pelakunya adalah wartawan. 


\section{Daftar Pustaka}

Assegaff, 1991. Dja'far H. Jurnalistik Masa Kini ( Pengantar Praktek Kewartawanan). Jakarta. Ghalia Indonesia.

Effendy. Dalam Pikiran Rakyat, 1 September 1990.

Hamzah, A. 1987. Delik-delik Pers di Indonesia, Jakarta. Media Sarana Press.

Hoeta Soehoet . 2003. Dasar-Dasar Jurnalistik. Jakarta. IISIP.

La Boueuf. 1992. Methode Penelitian. Jakarta. Grasindo.

Lsbandi. 2004. Dasar - Dasar Jurnalistik. Surabaya. Kartika.

Nuruddin. 2003. Sistem Komunikasi Indonesia. Jakarta. Rajawali Pers.

Onong Uchjana Effendy. 1992. Dinamika Komunikasi, Bandung. Remaja Rosdakarya.

Parakitri Simbolon. 1997. Vademekum Wartawan. Jakarta. Gramedia.

Rosentiel, Kovach, Bill. 2003, Sembilan Elemen Jurnalisme. Jakarta. Pantau.

Siebert. 1986. et al. Etika Pers Profesional Dengan Nurani. Bandung. Humaniora Utama Pers.

Sudarminta. 1993. Methode Penelitian Komunikasi. Medan. USU Press.

Widodo. 1997. Tehnik Wartawan Menulis Berita di Surat Kabar dan Majalah. Surabaya. Indah.

Winarto, 2003. Paulus. How To Handle The Journalist. Jakarta. Elex Media Komputindo. 